
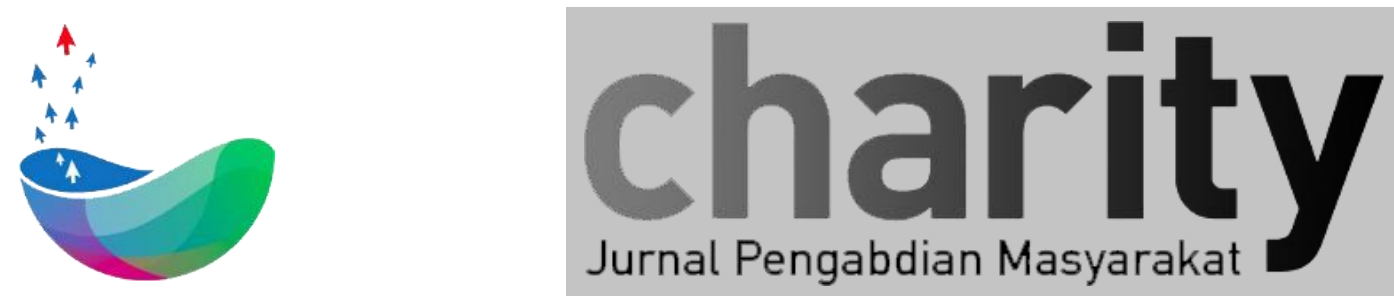

\title{
GERAKAN REBRANDING DIGITAL DAN PEMBANGUNAN APLIKASI KELOLA REDESAIN KEMASAN UMKM
}

Anak Agung Gde Agung ${ }^{1, *}$, Robbi Hendriyanto ${ }^{2}$, Agus Maolana Hidayat ${ }^{3}$, Pramitha Aulia ${ }^{3}$, Fauzan Aziz ${ }^{3}$, Arlin Ferlina Moch. Trenggana ${ }^{3}$, Nadya Novandriani Karina Moeliono ${ }^{3}$, Candra Wijayangka ${ }^{3}$, Arry Widodo

' Program Studi Sistem Informasi Akuntansi, Fakultas Ilmu Terapan, Universitas Telkom

${ }^{2}$ Program Studi Sistem Informasi, Fakultas Ilmu Terapan, Universitas Telkom

Program Studi Administrasi Bisnis, Fakultas Komunikasi dan Bisnis, Universitas Telkom

* agung@tass.telkomuniversity.ac.id, robbihen@telkomuniversity.ac.id, agusmh@telkomuniversity.ac.id, mithpsy@telkomuniversity.ac.id,

fauzanaziz@telkomuniversity.ac.id, arlinferlina@telkomuniversity.ac.id, nadyamoeliono@telkomuniversity.ac.id, wijayangka@telkomuniversity.ac.id, arrywie@telkomuniversity.ac.id

\section{INFO ARTIKEL}

Diterima 30 Maret 2021

Direvisi 27 Oktober 2021

Disetujui 10 November 2021

Tersedia Daring 04 Februari 2022

Keyword: rebranding digital, aplikasi,

\begin{abstract}
ABSTRAK
Di masa pandemi, gaya penjualan secara daring mengalami peningkatan yang sangat pesat. Hal ini disebabkan oleh pembatasan sosial, sehingga konsumen lebih memilih metode interaksi yang tidak mengharuskan kontak fisik. Paguyuban Pengusaha Kecil dan Menengah (PPKM) Kabupaten Bandung merupakan paguyuban yang menaungi Usaha Mikro Kecil dan Menengah (UMKM) di wilayah kabupaten Bandung. Dalam masa pandemi, UMKM binaan kalah bersaing dalam penjualan daring yang sudah ada, karena desain produk dan branding yang kurang menarik, atau 'kekinian'. Beberapa masalah yang berhasil diidentifikasi oleh PPKM adalah kemasan produk para anggota UMKM yang dikemas dengan biasa saja tidak memberikan ciri khas produknya sehingga kurang menarik dimata konsumen, logo dan merek produk UMKM yang minimalis dan ala kadarnya juga dinilai merupakan permasalahan dalam penjualan produk.Untuk itu kegiatan pengabdian kepada masyarakat kali ini bekerjasama dengan PPKM untuk membantu permasalahan dengan melakukan rebranding produk secara digital dan pembangunan aplikasi kelola redesain kemasan produk UMKM binaan PPKM.
\end{abstract}

kemasan, UMKM

Korespondensi:

Fakultas Ilmu Terapan Universitas Telkom

Jl. Telekomunikasi No. 1, Terusan Buah Batu, Bandung, 40257

Indonesia.

E-mail : agung@tass.telkomuniversity.ac.id

ORCID ID:

Penulis Pertama: 0000-0002-7593-5500

https://doi.org/xxx

Paper_reg_number xxx (C) The Authors. Published by Directorate of Research and Community Service, Telkom University.

This is an open access article under the CC BY-NC 4.0 license (https://creativecommons.org/licenses/by-nc/4.0/) 


\section{Pendahuluan}

Penjualan daring dapat lebih menguntungkan dibandingkan penjualan konvensional yang mempertemukan fisik penjual, pembeli, dan barang yang diperjualbelikan, sebab pihak penjual tidak membutuhkan sewa tempat, membutuhkan lebih sedikit pegawai, dan tidak perlu membayar beban seperti listrik dan air. Namun, mengubah konsep penjualan dari konvensional ke penjualan daring menimbulkan tantangan bagi penjual, di antaranya adalah desain kemasan. Pada penjualan konvensional, kemasan menjadi kurang penting karena calon pembeli dapat berinteraksi melalui berbagai cara, seperti melihat, meraba, dan mencoba produk yang diminatinya.

Dalam penjualan daring, calon pembeli hanya dapat melihat foto kemasan dan membaca deskripsi yang dicantumkan oleh pembeli di marketplace. Oleh sebab itu, desain kemasan menjadi salah satu penentu utama bagi calon konsumen dalam memutuskan untuk membeli suatu produk, terutama pada produk yang belum memiliki brand yang sangat kuat.

\subsubsection{Digital Branding}

Era digital menyebabkan perubahan cara pandang dan berperilaku dalam organisasi, termasuk kegiatan penjualan [1] [2]. Media digital dapat menjadi media pemasaran yang sangat efektif, jika perusahaan dapat menciptakan hubungan positif antara merek dan konsumen. Merek menjadi sangat penting sebab dalam pemasaran digital, merek menjadi interface antara produk dan konsumen [3]. Selain itu, media digital dapat menjadi media yang ampuh untuk membangun kesadaran merek produk di masyarakat [4], sehingga pada akhirnya pemasaran digital dapat meningkatkan pendapatan dan kesejahteraan UMKM [5].

\subsubsection{Desain Kemasan}

Desain kemasan berfungsi untuk mengkomunikasikan produk secara visual. Dari sudut pandang penampilan, tanpa desain kemasan yang berbeda, semua produk akan terlihat sama sesuai dengan jenisnya. Idealnya, ketika desain kemasan mampu memberikan informasi yang jelas dan spesifik kepada konsumen (baik langsung maupu tidak langsung), dan salah satu pembanding (di mana satu produk tampak merupakan produk yang lebih efektif, nilainya lebih baik, kemasannya lebih baik dipandang), pembeli lebih termotivasi untuk membeli produk tersebut. Dengan tujuan utamanya untuk mengalahkan kompetitor, menghindari kebingungan konsumen, dan mempengaruhi konsumen untuk membeli, desain kemasan menjadi faktor penting dalam keberhasilan rencana pemasaran merek perusahaan yang terintegrasi [6].

\section{Mitra Kegiatan dan Masyarakat Sasar}

Berdasarkan kondisi yang telah dipaparkan sebelumnya, kegiatan pengabdian kepada masyarakat kali ini menyasar UMKM di Kabupaten Bandung. Data yang diperoleh dari Dinas Koperasi dan Usaha Kecil Jawa Barat, 98,49\% usaha di Jawa Barat merupakan Usaha Mikro Kecil, dengan distribusi di Kawasan Bandung sebagai berikut. 
1. Kota Bandung sebanyak 333.112 usaha.

2. Bandung Barat sebanyak 155.041 usaha.

3. Kabupaten Bandung sebanyak 348.858 usaha.

Untuk itu, kegiatan ini bermitra dengan Paguyuban Pengusaha Kecil dan Menengah (PPKM) Kab.Bandung, yang dibentuk pada tanggal 25 Januari 2017 di Gedung Moh. Toha, Soreang, PPKM dibentuk atas keinginan bersama untuk membuat wadah yang menjadi ajang silahturahmi dan bersinergi.

Paguyuban ini mengelola UMKM yang tersebar di 31 Kecamatan di Kabupaten Bandung dengan berbagai jenis usaha, seperti yang terdapat pada Gambar 1.

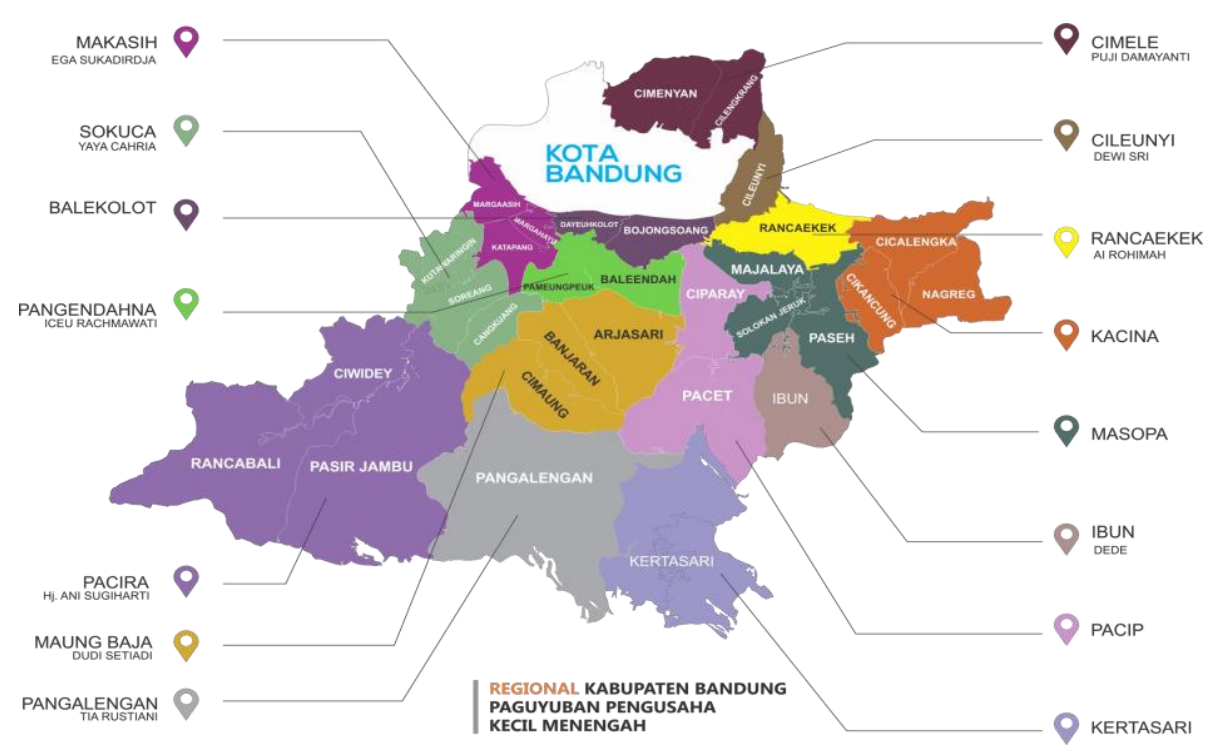

Gambar 1 Daerah Binaan PPKM

Jenis usaha yang menjadi anggota dari PPKM sebagai berikut dapat dilihat pada Gambar 2.

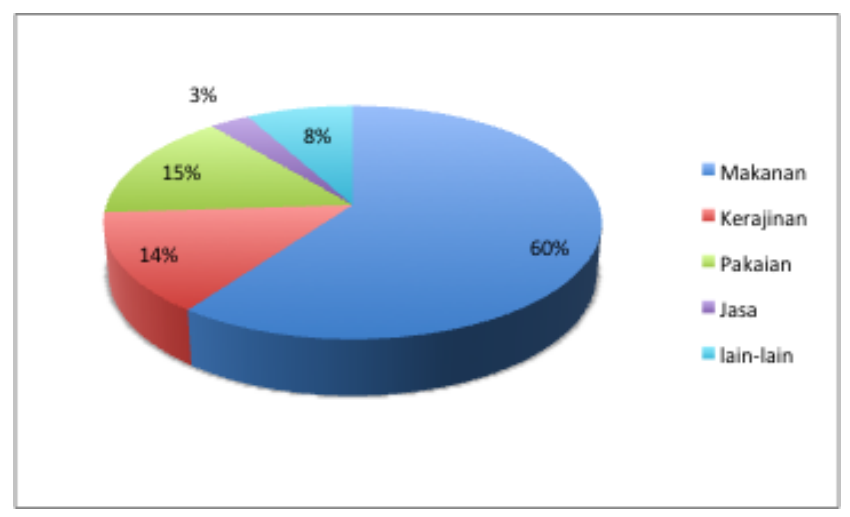

Gambar 2 Jenis Usaha PPKM

PPKM ini didominasi oleh pengusaha makanan baik kemasan ataupun non kemasan, diikuti dengan kerajinan, pakaian dan Jasa. 


\section{Permasalahan dan Solusi yang Ditawarkan}

Dalam kondisi pandemik, UMKM harus pandai melihat peluang usaha meskipun ada pembatasan aktivitas di luar rumah. Salah satunya memanfaatkan transaksi dan pemasaran secara daring, agar masih dapat menggaji karyawan dan tidak bangkrut. Proses marketing merupakan tonggak perjuangan UMKM di masa pandemi dinilai harus dinaikkan levelnya. UMKM masih menggunakan cara penjualan mulut ke mulut, dan menggunakan media sosial atau marketplace tanpa mengetahui bagaimana mengiklankan lapaknya kepada calon konsumen. Selain itu pengemasan produk sampai dengan desain merupakan modal utama untuk menarik konsumen [7] [8].

Berdasarkan hasil wawancara dengan pengurus PPKM, diidentifikasi pemasalahan sekaligus kebutuhan yang akan diupayakan solusinya sebagai berikut:

1. Kemasan produk para anggota UMKM yang dikemas dengan biasa saja tidak memberikan ciri khas produknya sehingga kurang menarik dimata konsumen.

2. Logo dan merek produk UMKM yang minimalis dan ala kadarnya dinilai merupakan permasalahan dalam penjualan produk.

3. Pihak komunitas berharap dapat memfasilitasi bantuan untuk melakukan desain ulang kemasan dengan bekerjasama dengan institusi lain, sehingga dibutuhkan sebuah sarana untuk mengelolanya.

Berdasarkan pemasalahan mitra maka diusulkan solusi penyelesaiannya sebagai berikut:

1. Membangun aplikasi desain ulang kemasan UMKM berbasis Website.

2. Gerakan desain ulang digital UMKM pada Komunitas.

3. Redesain kemasan UMKM pada Komunitas PPKM.

\section{Metode Pelaksanaan dan Gambaran IPTEKS yang Ditransfer}

Metode pelaksanaan yang diusulkan dalam bentuk tiga kegiatan utama didetailkan pada Tabel 1 berikut.

Tabel 1. Metode Pelaksanaan

\begin{tabular}{|l|l|l|} 
No & \multicolumn{1}{|c}{ Kegiatan } & \multicolumn{1}{c|}{ Metode Pelaksanaan } \\
\hline 1 & $\begin{array}{l}\text { Membangun aplikasi redesain kemasan } \\
\text { UMKM berbasis Website }\end{array}$ & $\begin{array}{l}\text { Analisa kondisi dan kebutuhan } \\
\text { mitra/masyarakat sasar dan pembangunan } \\
\text { aplikasi }\end{array}$ \\
\hline 2 & $\begin{array}{l}\text { Gerakan rebranding Digital UMKM pada } \\
\text { komunitas PPKM }\end{array}$ & $\begin{array}{l}\text { Pendampingan dan Implementasi desain ulang } \\
\text { digital produk UMKM }\end{array}$ \\
\hline 3 & $\begin{array}{l}\text { Redesain kemasan UMKM pada komunitas } \\
\text { PPKM }\end{array}$ & $\begin{array}{l}\text { Pendampingan dan redesain kemasan produk } \\
\text { UMKM }\end{array}$ \\
\hline 4 & $\begin{array}{l}\text { Pelatihan desain dan desain ulang produk } \\
\text { UMKM }\end{array}$ & \begin{tabular}{l} 
Menyiapkan materi dan pelaksana \\
\hline
\end{tabular}
\end{tabular}

Gambar 3 menggambarkan IPTEKS yang ditransfer ke masyarakat sasar. 


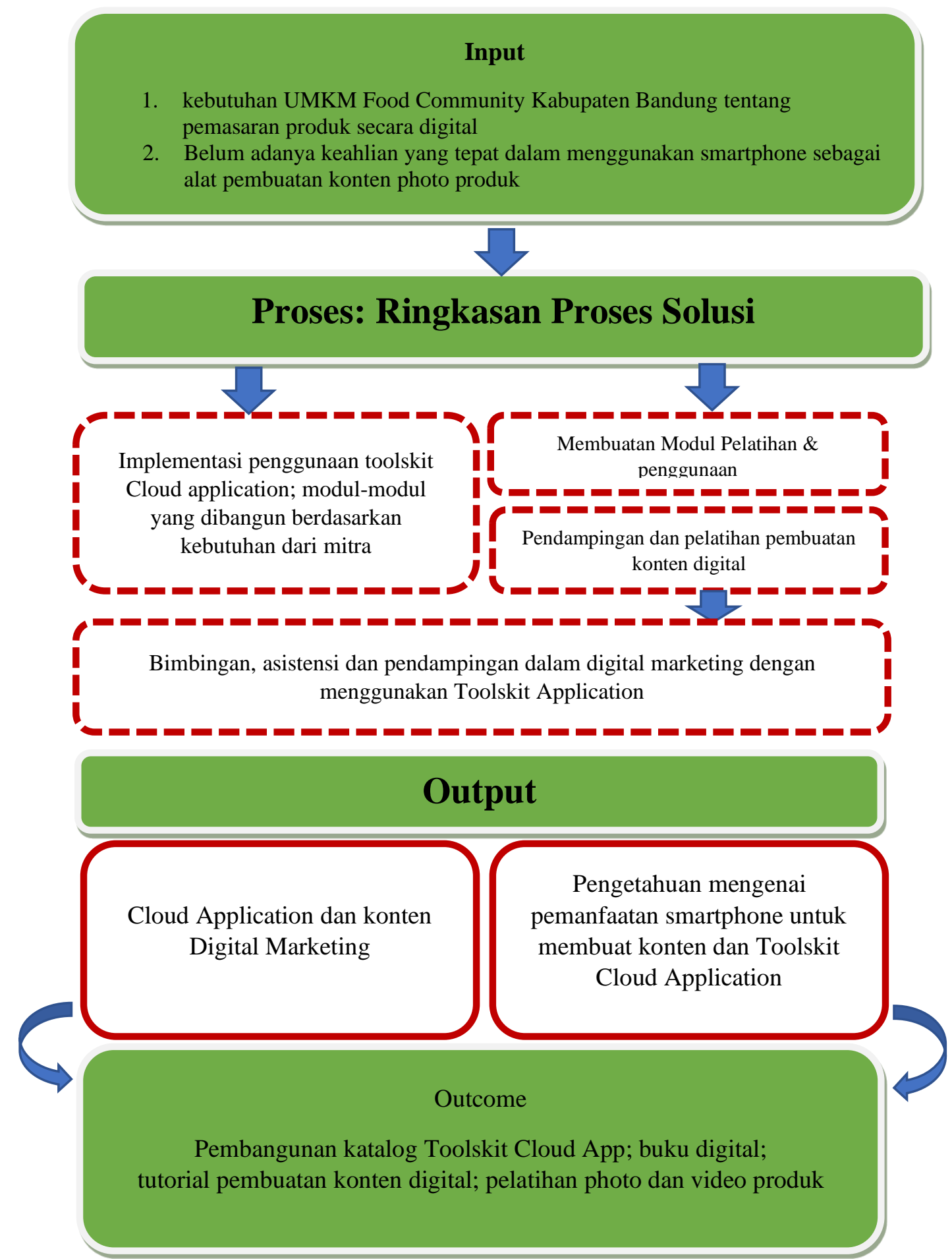

\section{Evaluation \\ Evaluasi pelaksanaan kegiatan}

Gambar 3 Gambaran IPTEKS yang ditransfer 


\section{Hasil Kegiatan}

Aplikasi redesain kemasan dapat diakses melalui tautan https://branding.ppkm.info/ (Gambar 4). Melalui aplikasi ini, masyarakat dapat mengembangkan bidang branding, packaging, serta konsultasi bisnis yang sedang berjalan saat ini.

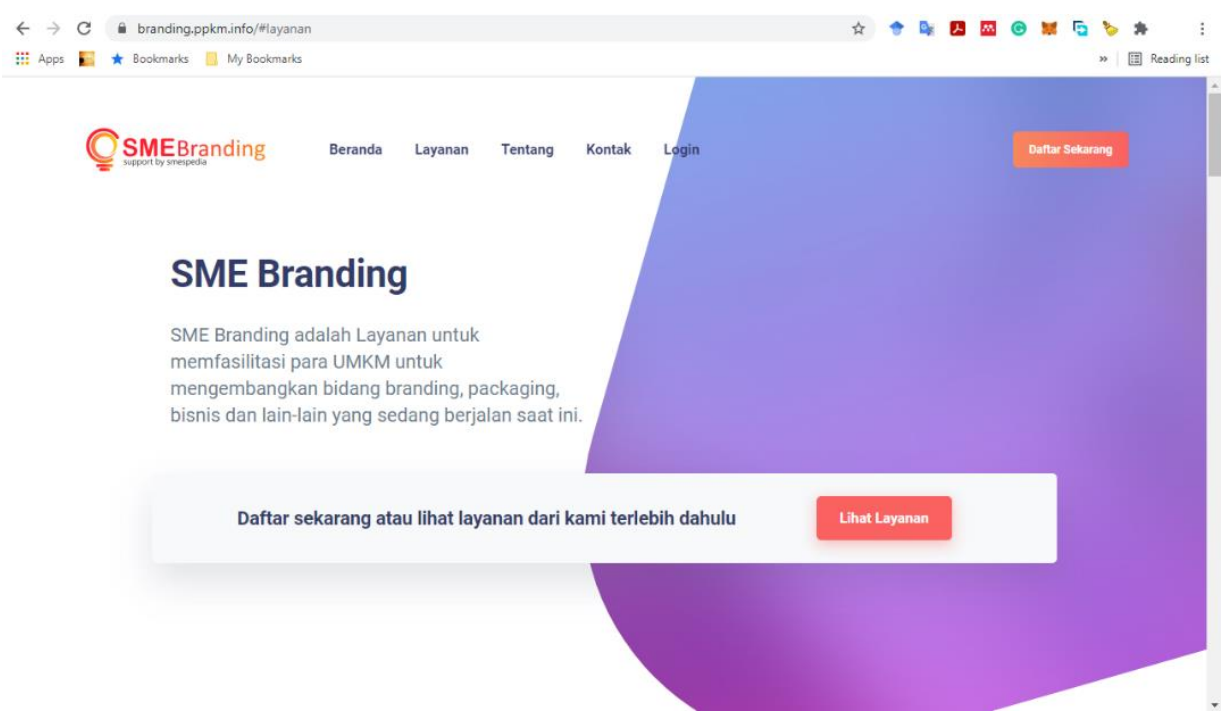

Gambar 4 Aplikasi redesain berbasis web

Beberapa contoh hasil rebranding kemasan yang dilakukan di antaranya sebagai berikut (Gambar 5). Gambar 6 menampilkan pelatihan desain dan rebranding yang dilakukan secara daring.

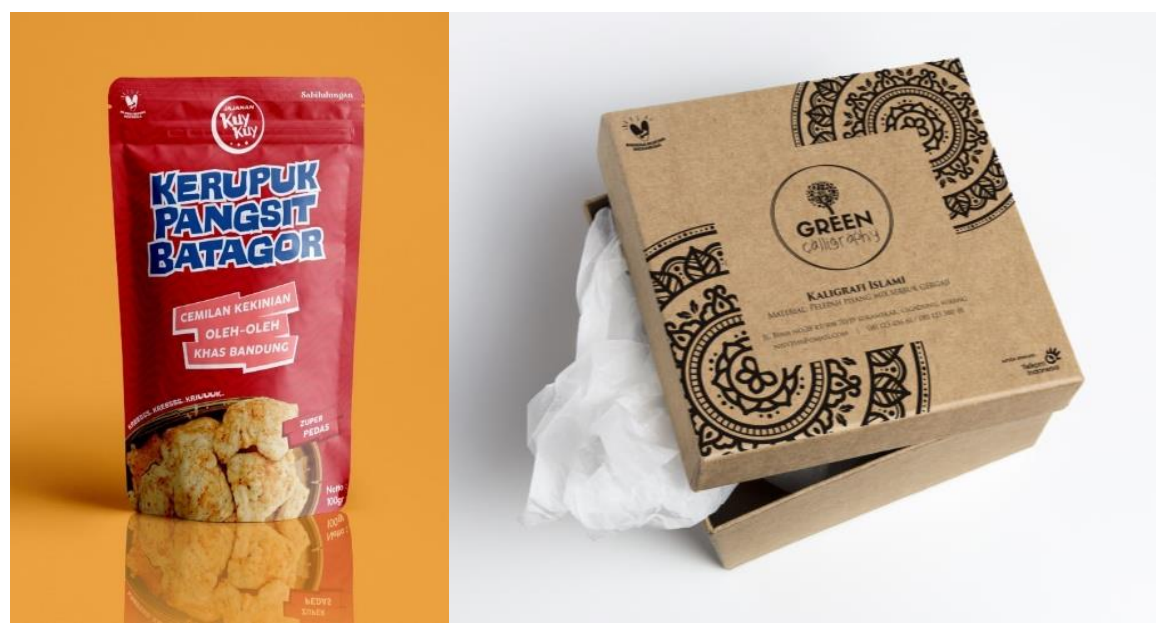

Gambar 5 Contoh redesain kemasan

Tabel 2 berisi penilaian yang merupakan feedback kegiatan. Penilaian dilakukan melalui kuesioner yang diisi oleh masyarakat sasar setelah pelaksanaan kegiatan. Dari feedback tersebut, diperoleh informasi jumlah penilaian positif terhadap kegiatan adalah sebesar $100 \%$. 


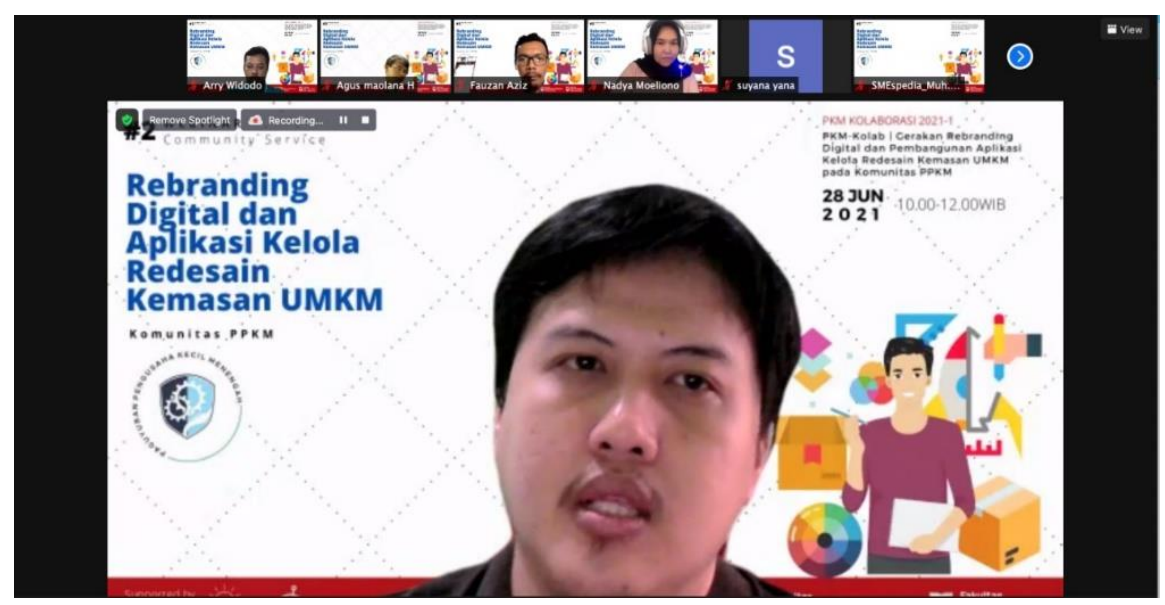

Gambar 6 Webinar desain dan rebranding

Tabel 2. Feedback Kegiatan

\begin{tabular}{|c|c|c|c|c|}
\hline Penilaian Terhadap Kegiatan & $\begin{array}{l}\text { Sangat } \\
\text { Setuju }\end{array}$ & Setuju & $\begin{array}{l}\text { Tidak } \\
\text { Setuju }\end{array}$ & $\begin{array}{l}\text { Sangat } \\
\text { Tidak } \\
\text { Setuju }\end{array}$ \\
\hline $\begin{array}{l}\text { Program Pengabdian kepada Masyarakat ini sudah } \\
\text { sesuai dengan tujuan kegiatan itu sendiri. }\end{array}$ & 20 & 0 & 0 & 0 \\
\hline $\begin{array}{l}\text { Program Pengabdian kepada Masyarakat ini sudah } \\
\text { sesuai dengan kebutuhan masyarakat sasarnya. }\end{array}$ & 19 & 1 & 0 & 0 \\
\hline $\begin{array}{l}\text { Waktu pelaksanaan program pengabdian } \\
\text { masyarakat ini relatif telah mencukupi sesuai } \\
\text { kebutuhan. }\end{array}$ & 15 & 5 & 0 & 0 \\
\hline $\begin{array}{l}\text { Dosen dan mahasiswa Universitas Telkom } \\
\text { bersikap ramah, cepat dan tanggap membantu } \\
\text { selama kegiatan. }\end{array}$ & 19 & 1 & 0 & 0 \\
\hline $\begin{array}{l}\text { Masyarakat setempat menerima dan mengharapkan } \\
\text { program pengabdian kepada masyarakat } \\
\text { Universitas Telkom saat ini dan masa yang akan } \\
\text { datang. }\end{array}$ & 20 & 0 & 0 & 0 \\
\hline $\begin{array}{l}\text { JUMLAH "SANGAT SETUJU" + "SETUJU" } \\
100 \%\end{array}$ & \multicolumn{4}{|c|}{$100 \%$} \\
\hline
\end{tabular}

\section{Kesimpulan}

Kegiatan pengabdian ini telah berhasil memenuhi target luaran yang diharapkan, yaitu pembuatan aplikasi rebranding kemasan berbasis web, melakukan gerakan rebranding digital UMKM pada komunitas PPKM, redesain kemasan produk yang dimiliki oleh UMKM binaan PPKM, serta membuat pelatihan desain dan rebranding produk yang diselenggarakan secara daring. Feedback yang disampaikan oleh mitra sasar secara umum sangat baik, dibuktikan dengan jumlah 'sangat setuju' dan 'setuju' yang mencapai $100 \%$. 


\section{DAFTAR PUSTAKA}

[1] R. Deiss and R. Henneberry, Digital Marketing For Dummies, 2017.

[2] Digital Marketing: Intro, Books Team.

[3] S. Boric, S. Stanisavljev, M. Kavalić, M. Vlahović and E. Tobolka, "Analyisis of digital marketing and branding for the purpose of understanding the consumers in digital age," in International conference on Applied Internet and Information Technologies, 2016.

[4] A. V. Riskyawa and R. M. Ervianty, "The Use of Digital Marketing Communication Media As A Tool To Achieve Brand Awareness of Kitchenindo Products," The International Journal of Applied Business, vol. 3, no. 1, 2019.

[5] S. R. P. D. Harto, M. N. Utomo and M. Rahmawati, "Penerapan Internet Marketing dalam Meningkatkan Pendapatan Pada UMKM," Jurnal Pengabdian dan Pemberdayaan Masyarakat, vol. 3, no. 1, pp. 39-45, 2019.

[6] M. R. Klimchuk and S. A. Krasovec, Desain Kemasan, Jakarta: Erlangga, 2007.

[7] Bank Indonesia, "MSME Development requires a Conducive Ecosystem," [Daring]. Available: https://www.bi.go.id/en/ruang-media/info-terbaru/Pages/Pengembangan-UMKM-MembutuhkanEkosistem-yang-Kondusif.aspx.

[8] D. S. M. Juhro, "Pembangunan Inklusif Bagi UMKM di Era Digital," Bank Indonesia, 2018. 